\title{
The Problem of Nationalism, "Nigeria" As a Contested Category and the Quest for a Social Philosophy of National Integration
}

\author{
Philip Ogochukwu Ujomu*
}

\section{Abstract}

This paper examines the problem of nationalism in Nigeria construed as the search for a basis on which the members of the society can claim a sense of belonging, identity and common purpose. There is a problem of the national question here because ethnicity, corruption, disobedience to law and order, disdain for the rule of law and accountability and the disregard for the value of human life have undermined the social order and eventually created an army of the vulnerable and marginal peoples that can be manipulated for parochial ends. The apparent underperformance of the various instruments of the state such as the police, national assembly, appointed ministers, law courts, prisons, etc, due to inefficiency, injustice, under-funding, politicization and social dissatisfaction have threatened the unity of Nigeria and highlighted deficits in the social order that have made Nigeria to appear as a contested construct or category. Given the above we seek a philosophical approach to building a social system or social philosophy of national integration.

* Dept of Philosophy and Religions, Faculty of Arts, University of Benin, Benin-City, Nigeria; pujomu@yahoo.com 


\section{Introduction and Problem}

Every state or society is known by the nature and quality of justice that it provides and maintains. These principles include fundamentally the rules of fair or equitable treatment of the members of society, the equality of opportunity for progress available to the citizens, the level of social and physical infrastructure corresponding to the quality of life of the people and the upholding of humane and human values of freedom and responsibility for human dignity. Social justice aims at a pattern of fair treatment for people. The primary subject is the way in which the major social institutions distribute fundamental rights, duties and determine the division of advantages from social cooperation according to certain principles of equitable, fair and humane distribution of benefits and burdens. The attempt is to reconcile opposing views and desires, and work out a mutually beneficial and an equitable means of producing and sharing social goods.

In the Nigerian postcolonial setting the rule of justice is obstructed by negative application of ethnicity, corruption, disobedience to law and order, disdain for the rule of law and accountability and the disregard for the value of human life and the common good. The problem of creating African societies where justice will be a reality for all, especially the vulnerable and marginal peoples, is currently a priority concern when, seen in the context of the deterioration of many African societies into spectral failures of the various instruments of justice, such as the police, national assembly, appointed ministers, law courts, prisons, etc. The operations of these institutions have been defeated largely by inefficiency, under-funding, incompetence, ethnicity, politicization and social dissatisfaction. Nigeria is affected by the above weak points, the most vivid of which is the procedural and social justice issue. Thus Nielsen (1996:82) puts it succinctly that "the question of justice is the question of what is that genuine social order that can guarantee human flourishing (and) social harmony in which people acknowledge their communal nature and their self-autonomy" (Nielsen, 1996:81-82). 
In the real life experiences of Nigerian citizens there is a lack of effective rules, structures and institutions that can guarantee the preservation of the dignity and worth of the human person as a free and responsible agent. There is apparently an absence of a genuine commitment to the values of trust and dialogue as such these values have been undermined by poverty, ignorance, ethnic biases and religious extremism. These shortfalls have led to the demands for institutional arrangements for the rectification of injustices and marginalization. Evidently the demands of the numerous aggrieved groups focus on the need for installing elaborate procedures of fair treatment and negotiation which will counter balance the reality of insecurity and marginalization of the various social groups in the physical, political, economic and social realms of life. Basically, the economic gap can be seen in the contrasts in nutrition, education, disease patterns, family size and life expectancy (Brown 2008: 107).

It is clear that "part of the challenges facing the state in a globalizing world are still classic internal ones, the incomplete construction of nation-state identities; (the) deliver(y) (of) effective services, difficulty of controlling crime and violence. However, financial transactions, microbes and weather patterns do not respect national borders" (Ferguson 2006:7). While almost every society faces challenges of maintaining social control and attaining social justice yet the chances of success at overcoming these obstacles found in every human society brighten or wane depending on the innate character of the society as shown by the human factor or agency. The viability and stability of a society depends on the current behavior and experiences of the human beings and also the way that the society was formed ancestrally. Was the society formed by conquest, association or agreement? What exactly does the name of that society symbolize to all members or social contributors? Let us examine the concept of Nigeria as a category in dispute. 


\section{An Exploration of the Term 'Nigeria' as a Contested Concept}

The idea of Nigeria is a contested category. By having this character, it throws up a multiplicity of interpretations and nuances that are fluid and flexible. This variability leads to contextual meanings that almost defy logic of definition and agreement of purpose. The end result is an emergent scheme of contradictory and convoluted meanings and consequences that have made the term to be something quite nebulous. Which sense of the word Nigeria are we talking about? Whose Nigeria are we talking about? What attitude to Nigeria are we talking about? What meaning does Nigeria have to different persons, institutions and groups?

There cannot be a mono-logical definition of Nigeria. This is so because there are certain fundamental concerns and questions of nationhood and justice that need to be systematically and properly clarified. When we refer to 'Nigeria' do we mean that name or that contraption that was put together by Lord Lugard and his acolytes? Is 'Nigeria' that honey pot or economic system that is being milked dry by the neocolonialist leaders and foreign business interests, just as it was plundered by the metropolitan colonizers of old? What feelings does the name 'Nigeria' evoke in those individuals and groups that have suffered inequity, injustice, oppression, extra judicial killings, ritual killings, armed robbery, illegal arrests, kidnapping, extortion, murder, unfair treatment and incompetence and transnational terrorism at the hands of the state, its agencies, contractors and military forces, militia and other illegally armed groups?

What definition of 'Nigeria' would be proffered by the people of Bakassi, Ogoni, Niger Delta as a whole who remain traditional victims of ancestral oppression and inequity? How would this classes of persons view the country - Nigeria: We have vulnerable peoples all over the country; women, rural people, casual workers in factories across the country, uneducated, unemployed graduates, destitute persons nationwide, the aged, the pensioners, those who are physically challenged, children especially girls, widows raped 
and abused by entrenched forces of anachronism in the family and in the society, quite a number of innocent persons who are unlawfully detained in police cells and in detention custody in prisons nationwide where they have served more time in punishment than if they had actually been sentenced lawfully, those persons tortured, maimed and killed brutally by the institutional security forces and the rebellious insurgents and terrorists?

The character of Nigeria is basically that of a place suffering social dislocation, a crisis of identity, a domain of contests and conflicts. For example, we can use the metaphor of a martial contest to illustrate the relations between Nigerians and some of the institutions meant to serve the people, but which in fact have turned against them become the reprehensible signposts of oppression and inefficiency in the society. There is a situation where PHCN the country's electricity producer and supplier versus the people of Nigeria whereby there will be little or no electricity supply for the month and yet the distribution companies will charge citizens VAT value added tax, fixed charges for services not rendered. This situation is aggravating and reprehensible. There is also the scourge of poorly maintained roads, inadequate security, lack of potable water supply and poor educational service delivery among others. There is the situation of the government versus the people of Nigeria.

The fundamental problems confronting Nigeria have not altered significantly in the past decades. The basic problems have centered on the ideas of unity, security and social justice as well as the interfaces between these. There is a problem of the meanings of these ideas for different segments of the society. There is a security problem in Nigeria, highlighting the security of the few in the seat of power versus the security of the bulk of the citizens. Nigeria's security problem is easily seen in the inability of the Nigerian government and the country at large, to ensure the protection of its core values; its territories, infrastructure, officials, citizens, laws and institutions. This has ensured that the various governments and the state agencies have been unable to consistently and 
institutionally guarantee the adequate protection, peace and well being of the generality of the citizens. The security problem is bigger than any group or institution and represents a crisis of community otherwise, the absence of shared core values and institutionalized mutual cooperation for the common good.

There is the issue of the Nigerian people versus national and international Boko Haram terrorism in Nigeria's north east. As an example, over three years 2010-2013, more than 3500 persons have died as a result of the group's actions (Agbiboa 2013:65,72 \&79). The violence of July 2009 alone in which the Boko Haram leader Mohammed Yusuf was extra judicially killed by the police claimed the lives of at least 1000 persons. The violence spread to six northern states- Borno, Bauchi, Gombe, Yobe, Kano and Katsina. In Borno alone 500 members of the group were killed by the security forces, in all 3500 persons were internally displaced, 1264 children orphaned, 392 women were widowed as well as 28 policemen, 5 prison warders, many soldiers, 48 buildings, 1 court, 3 schools, 12 churches were destroyed (Ogunrotifa 2013:48-49). In 2010 the group reemerged under Shekau to destroy Maiduguri prison releasing over 700 inmates, bombed Jos killing 80 people, attacking and destroying police stations, banks, military facilities, churches, mosques, schools, higher institutions (Ogunrotifa 2013:50).

At the last count Boko Haram has eliminated over 2000 persons since the campaign started in 2009 (Vanguard Newspapers 2014 Saturday 29 November). There has been a special attack on the girl child by the terrorists who use them for sex slavery and human trafficking. In December 2014 over 276 young women were abducted. A similar abduction of over 200 girls occurred in April 2014. Vigilante groups, native hunters and trackers have joined the military in the fight against the terrorists (Vanguard Newspapers 2014 Friday 19 December). The most recent statistics available suggest that more than 13000 persons have been killed and more than 1.5 million have been displaced and scattered both within Nigeria and outside in its neighboring countries.

Beyond the above challenges of a turbulent and dislocated society, one way of reviewing the problem of Nigeria as a contested 
category is to review our dominant social paradigm DSP. The DSP problem is seen in its effects on human and national security. Basically our security problems encapsulated in the inability of most governments and the state agencies to consistently and institutionally guarantee the adequate protection, peace and well being of the citizens. This shortfall or weak point arises due to ideological and often violent tussles between competing ethnic, economic and religious interests seeking to establish their parochial particular values as the primary dominant social paradigm DSP. Thus there is a need for a rectification of immanent shortfalls in Nigeria's Dominant Social Paradigm (DSP), corrupt leadership, warped state centric security, ethno religious conflicts" (Ujomu 2009:21-23). In Nigeria in the last couple of years crime and criminality have reached a crescendo. The combined activities of armed robbers, hired assassins, arsonists, political thugs and abductors have unleashed terror on the civil populace, making life extremely unbearable."(Ozohu-Suleiman and Baba 2009:47).

Ajibola (2010:11) argues that "Nigeria is the most populous nation in Africa, we are deprived of the ordinary basic needs of life as a result of endemic corruption which has now overwhelmed us. Generally the situation of our infrastructure is appalling. Another disturbing situation in our country at the moment is the state of insecurity. People are being killed with impunity, we are now at the mercy of hoodlums, armed robbers, kidnappers and all these die-hard criminals." (Ajibola in Gyamfi 2010:11). Braithwaithe concurs with the above when he says that "an unprecedented and widespread corruption in governance and injustice have combined to engender insecurities, insurgencies, heightened criminalities, widespread unemployment, all in the face of mindless profligacy of the corrupt" (Braithwiathe 2012:10). This situation that revolves around "the quality and manner of life as the poor majority are banished to the ghettos where there is no electricity, water supply or sanitation facilities, as armed robbery, hooliganism, prostitution have become a way of life" (Okonta and Douglass in Osha 2006:15). 
It is not clear that anything has significantly changed on the Nigerian landscape. According to more recent documents like the CENCOD 2011 annual report (2011: ix-xi) "Nigerians still face varying forms of human rights violations. The state is still largely authoritarian as security forces trample on the rights of the citizens with surprising impunity unexpected in a democracy. This often takes the form of harassment, extortion, unlawful detention and extra judicial killings. There are reports of misappropriation and misapplication of state resources by incumbent state actors" as well as local authorities and foreign business interests. According to the CENCOD 2011 annual report 2011 the common people have been driven beyond the poverty threshold "the unemployment rate in the country is alarming. It is perhaps one of the major causes of crimes involving youths such as armed robbery, internet scams, and kidnapping" (CENCOD 2011 annual report 2011:xi). Beyond the general trends there were specific patterns in the trend of social disorder, national insecurity and problems of human dignity in Nigeria.

According to the CENCOD 2011 annual report (2011:xii-xviii) predominant among the challenges were cases of kidnapping, violation of the right to worship, harassment by security forces, extrajudicial killings, assault on liberty, desecration of the right to life, violations of women's rights, witchcraft accusation, money making ritual, armed bandits, intra communal clashes, gun battles between criminal gangs and local vigilante groups, student union protests, child abuse, assault on the press, political intolerance, illegal sects. Again according to the CENCOD 2012 annual report (2012: xi-xii) "the harsh economic policies foisted on the people by the ruling elites underpin the rising social violence in the country and were accountable for the upsurge of violence and violations recorded. The Boko Haram sect insurgent activities increased. The northern half of the country became a battlefront with waves of suicide bombing and killing of innocent citizens culminating in the total collapse of governance and institutions of government in the affected states." The central feature in the quest for national security is the concern for national survival, peace and progress. This lack of formulation concept that encourages peace and the 
pursuit of the common good have triggered a problem of national integration and unity.

The problem of unity is easily seen in the inability of the diverse ethnic and religious groups to coexist socially as a community by living together in peace through mutual respect and cooperation for the personal and common good of all concerned. The situation is that given the divisive nature of the Nigerian state and the ineffectiveness of its key executive and legislative organs, there has been a rise of ethnic and parochial interests whose basic argument is that the current configuration of the Nigerian state is not equitable and humane to all concerned. Hence, something should be done about this. In relation to the Niger Delta and indeed most parts of Nigeria "there is a deep seated feeling of neglect which lies at the root of widespread discontentment, grievances, conflict, criminality and violence."

Most of the communities lack basic necessities of life. Basic facilities like roads, portable water, electricity healthcare and education are completely absent in many communities and not functioning in others. Economic inadequacies predispose youth to violence and manipulation" (Report of the Technical Committee on the Niger Delta 2008 (2010:82, 93\& 107). Put simply, "the root causes of insecurity in the areas had to do with the neglect, frustration, and the sense of abandonment of the people. Security arrangements are inadequate and largely uncoordinated" (2002 Report of the Special Security Committee on oil producing areas 2007: 120\&132).

The is a link between the ill treatment of the human and natural resources of the oil producing southern Nigeria and the omnibus corruption network or syndicate that has become well entrenched in the society reaching even to the highest echelons of power. This situation has triggered resentment and reactions among the citizens. We can have an empirical account the House of Representatives Fuel Subsidy Probe Report, 2009-2011, (2012:62 \&63). The documents reports that "the mood of the nation is justifiably ill tempered." There is a conflict between the people's larger interest and the self interested clique of government officials seemingly out of tune with the existential realities of the ordinary 
man in the street. The Nigerian people from all social indicators are already impoverished by the maladministration of the political elite." To put the matter in a clearer perspective, "a large section of the population faulted the premise of the government subsidy figures maintaining that unbridled corruption and an inefficient wasteful process accounted for a large part of the subsidy crisis" (Editorial on the Removal of Fuel Subsidy, Guardian Newspapers. pp.62-68).

The crisis of national integration is primarily a social justice problem that is tied to concerns over endemic corruption. According to the House of Representatives Fuel Subsidy Probe Report 2009-2011 (2012: 129-130) the "NNPC continued to pressurize officials of other agencies, especially the PPRA to process and pay subsidy on the product....the NNPC and its Ministry merely arrogated to themselves the power to override the Presidential Directive." According to the House of Representatives Fuel Subsidy Probe Report 2009-2011 (2012:131) the "inefficiency of the NNPC, PPMC and Ministry of Petroleum reflected in the failure to supply the product to Nigerians at affordable pricing....to further underscore their inefficiency various agencies gave conflicting retail price of the product in the open market." The House of Representatives Fuel Subsidy Probe Report 2009-2011 (2012:74 \& 116) reports that "while the NNPC feasted on the Federation Account to bloat the subsidy payable, some of the Marketers took the option of claiming subsidy on products not supplied.

Also the state of our refineries is nothing to write home about as it appears that greed and corruption, etc, among operators in the downstream sector colluded to strangulate the refineries." There seems to be an established pattern of poor social service delivery as an adverse dominant social paradigm or DSP. In tracking the fundamental, perennial levity, laxity, aversion and indifference of the Nigerian state to social justice concerns and the tendency not to take potentially explosive issues seriously (Report of the Technical Committee on the Niger Delta 2008, 2010:87-88, 117. Izagbo (2012:14-15) summarizes the dismal picture by saying that "what 
Nigerians have had to face is the worst kind of parlous leadership marked by corruption, incompetence, porous borders and security lapses."

A further illustration reveals that the above situation is grave and disheartening and has made some people to argue that citizens have become 'local governments' or total service providers in their own right. It is quite troubling that an individual needs to provide himself all the social services in Nigeria: He buys a personal generator and fuels it to provide electricity. He sinks a personal borehole to give himself water. He buys land and builds himself a house to live in. He employs a security man to guard his life and property. He forms an association with fellow house owners on the street to contribute money to buy stones to fill the bad roads. He sends his wards to a private school where he pays high fees. These are the reasons why we pushed the position that one individual in Nigeria can as well act as a municipal or local government. It is therefore clear from the above that Nigeria is a contested category and no element of its reality can be taken for granted at the theoretical or analytical level if we are to make significant contribution to the theory and knowledge that can affect policy and praxis.

\section{Ethnicity, the Technology of Social Engineering and the Problem of Uneven Development}

From an historical viewpoint, it is instructive to note that a foremost Nigerian statesman- Azikiwe (1965) had made a crucial appeal for social transformation a long time ago. Azikiwe said that "Nigerian leaders must address themselves to the root causes of bad faith and suspicion in our body politic. We must be frank in tackling the problems which have arisen as a result of our decision to live together as one country" (Azikiwe 1965:456). If this call had been heeded, it might have made a difference in enhancing the direction of Nigeria's national project. Put simply, we cannot afford to shy away from the problematic and the conceptual navigations that emanate from what Uroh (1998:94) has informed us is the 
divisive character of the ethnic situation, which has ensured that a lot of groups and societies have remained in a state of discontent.

Evidently, the problems of ethnicity in Nigeria and the instability and conflicts arising thereof are multi-dimensional and lifethreatening. Ethnically charged societies face a multifaceted crisis that seems to put the question of individual and collective survival on the center stage. According to Odugbemi (2001) the rise and increase in ethnic nationalism has eroded the sense of national identity (Odugbemi 2001:67\&69). A similar point had been mentioned by Nisbet (1973:18) who argues that "the upthrust of ethnicity in our age" is nothing but a sign of the vanishing of political community which now gives rise to other forms of community. The complex forms and patterns of the consequences of ethnicity seem to be fully appreciated by some writers. In the case of Nigeria, Ifeka (2000:121) argues that conflict between the center and periphery (in its varied manifestations) has disrupted Nigeria's social and political development. In our view, since independence in 1960, the problem of ethnicity and the attending conflicts in Nigeria have centered on the experiences of the numerous individuals and diverse groups in the country, who are faced with oppression, marginalisation, insecurity, and poverty in a country so richly blessed with vast human material resources.

This situation has not really altered significantly from the past. Hence in a publication of the Committee for the Defence of Human Rights (CDHR 2000: ii) it is argued that the majority of the Nigerian people have continued to languish under situations of continued and heightened exploitation, frustration, violence and lack of progress. It is thus clear that "when cultural and other differences are manipulated into becoming the bases for armed confrontation, both the instigator and the instigated are consumed by the fires of the ensuing strife" (Usman 1999:63). The historical dimension to the ethnic and national conflicts in Nigeria has its roots in the precolonial era of Nigeria's history. According to Calvocoress (1997:612), even though the British colonialists assumed the task of mastering or moderating the conflict between the Fulani, Hausa and other ethnic groups, as a prelude to unifying all the colonial 
territories, yet the Nigerian federation which they created was an uneasy amalgamation of cultures and groups lacking national consciousness and unity. Furthermore, Seton-Watson (1977:348) holds that Nigeria was an artificial creation of British colonial rule. This large country contained many people, languages and religions. There were three main languages. In the North, Hausa was widely spoken, Yoruba was spoken in the southwest, and Igbo was spoken in the east. The West and the East both had a much higher level of education and modern skills than the North, and both were largely Christian, while the North was mostly Muslim. This situation was to provide a fertile ground for the endemic conflicts that would plague post independence Nigeria.

The cultural and religious factors that have given rise to the differences in educational status, values and attainment among the various ethnic groups in Nigeria have been emphasized by Kitchen (1962:364-365) who informs us that education has progressed much more rapidly in the South than in the Moslem North. Thus the general absence of national consciousness and unity arising thereof, has ensured that from time to time, there have been ethnically motivated or guided attempts by some groups (military or civilian) to break up the country. For example, there was the case of the Nigerian civil war (1967-1970), and also, the collapse of national life during periods in 1993, 1994 and 1995 following the annulment of the June 12 Presidential elections. According to Egwu (2000:4), the case of Nigeria illustrates quite vividly the collapse of the nationstate project.

In Nigeria the state has failed to manage effectively and imaginatively, the co-existence of multiple ethnicities in view of peaceful and progressive ends. Ultimately, the outcome of this has been the intensification of conflicts within, and between groups in the Nigerian society. In almost all of its history, politics in Nigeria has been defined according to regional parties aligned along ethnic dimensions. Diamond (1988:38-42) holds that since independence, politics in Nigeria has always been defined along regional lines. Political competition has thus always been characterized by ethnic prejudice and vituperative rhetoric, violence and repression. 
Hence, intolerance, violence and insecurity have been regular features of many elections and political regimes in Nigeria and this scenario has contributed significantly to the engendering of social conflicts in the country.

Central to the occurrence of ethnically induced political and economic conflicts in the Nigerian society is the problem arising from the counterproductive procedures by which the national elites have managed and distributed the limited national resources and wealth. According to Hawthorn (1993:336), public officials in positions of power have had to appropriate and distribute portions of the state resources. Given such situation, conflicts have arisen because of the improprieties involved in the distribution and redistribution of these resources. This has been mainly because of both the scarcity that pervades daily existence, and the nepotism and clientelism of the state and its officials. This situation has ensured that a disproportionate share of national resources has been generated for the political and economic ruling class. The political and economic conflicts that have beset the Nigerian nation have been anchored on the perception nurtured by certain interests and groups that they are being deprived of their share of the state's resources. This in turn has truncated efforts at social cooperation and stability.

According to Diamond (1988:10-11) the phenomenon of ethnic pluralism ethnic cleavages and the structure of centralized ethnic systems are a hindrance to social cooperation and national cohesion. This situation provides a fertile ground for ethnic conflicts and thereby poses a challenge to political stability in the country. Furthermore, the volatile conflict situations engendered by ethnic complexities in Nigeria have been worsened by the manipulation of class politics, which has aggravated the situation of conflict, insecurity and disorder in the Nigerian polity. With specific reference to the role of the Nigerian elite in engendering conflict in society, Graf (1983:189) says that the Nigerian dominant classes have evolved from a fractious, ethno culturally-centered and self seeking set of groupings, into a relatively cohesive, autonomous and self confident stratum capable of regulating its 
potentiality internecine conflict while pursuing its collective interests against the interests of other social strata. Graf (1983:195) argues that the processes of elite formation in Nigeria, was contingent on their capacity to meet the demands of their various ethno-political constituencies. This situation compels the elite, and subjects them to a cross pressure to divert or channel government resources to their ethnic and kinship group. This situation arises because the elites need the support of these ethnic groups in order to remain in power.

Such diversions and clientelism within the context of scarce national resources had to be accomplished at the expense of other elites' constituencies, thus, ensuring the permanence of conflicts over appropriation, resources and position within the country. Therefore, it appears that central to the endemic problem plaguing the Nigerian society remains the numerous differences between the groups inhabiting the country, and most importantly, the numerous injustices brought about by this situation. To this effect, Kemp (1998:179) holds that the differences in physical feature and resources, ethnic compositions, historically constituted patterns of cultural life, within the country called Nigeria, have ensured that regional differences persist and continue to widen. This conflict of values and the various abuses and injustices arising from it, ensured that there were no clearly defined and established rules for harmonizing the diverse interests, needs and values of the different groups and sectors in the society in view of achieving the urgent task of national development and the sustenance of security, peace and prosperity in the country.

\section{The Class Issue and the Problem of Marginality}

A sociologist Otite (1995) states that class can play a positive role in mitigating ethnicity. He asks us to "develop and strengthen class ties to subvert the strength of ethnicity in contemporary Nigeria" (Otite 1995:23). Is it the case that this approach will work? We need to understand the genealogy and contextualization of class to see whether such a function ascribed to class can easily be attained. Glazer and Moynihan (1963:12-17) have drawn attention to the fact 
that ties of kinship, friendship and interest connect men. Class theory was introduced to explain the gross inequalities in the ownership of wealth and income arising from the operation of a free market economy. Marxian theory had as a central feature among others the highlighting of the role of social classes in the creation and transformation of major types of society (Bottomore 1996:155-156). At that time, it drew attention to the conflict and opposition between two major classes, the bourgeoisie and proletariat, as well as the contradictions that result from this conflict.

Furthermore, Marx contents that the entire history of mankind can be described as a history of class struggles and contest between the oppressors and the oppressed. It is these class struggles that have led to a series of revolutionary transformations in the history of societies (Marx and Engels 1990: 426). That is about the theory of class, which in turn raises fundamental questions about the social structure of the society as it reflects on "the distribution of economic and political rewards among various competing interests and ethnic groups" (Said 1977:35). The character of resource distribution in Nigeria has become sufficiently simplified while at the same time the experience of the same has become increasingly harrowing.

It will not be presumptuous to say that in Nigeria, there are only two real classes that impact variously on the social dynamics; these are the rich and the poor. This present stage has evolved due to the fact that the state has failed to manage effectively and imaginatively, the co-existence of multiple ethnicities in view of peaceful and progressive ends. The ruling elites have continued to employ ethnic and regional affiliations and mobilization in the struggle for state power. The occurrence of political and economic conflicts arising from the counterproductive procedures by which the national elites have managed and distributed the limited resources and wealth managed and distributed the limited national resources and wealth, have created volatile conflict situations. The engendered by ethnic complexities in Nigeria have been worsened by the manipulation of class politics, which has aggravated the 
situation of conflict, insecurity and disorder in the Nigerian polity. Ake (1996:13) describes the Nigerian elites as self-absorbed and having no national project. "They know only their own interests."

Elite politics and conduct in Nigeria generally connotes the acquisition of wealth by corrupt practices. Politicians were willing to obtain power at all cost, since the control of power emphasized the control of the economic strings of the society (Nzimiro, (1984:36-37). Elite political administration is treated as a purely personal affair of the ruler, and political power is considered part of his personal property (Ibrahim, 1997:156). The point then is simply that once one manages to find himself or herself joining the core ruling elite that is configured in concentric rings of outwardly diminishing power-holding, then one has joined the only class that matters. This induction or inclusion is irrespective of one's ethnic affiliation. What serves as the basis of admission into the class of the rich, are the dominant metropolitan beliefs and values held by people. At this level, closure of all spaces, insensitivity at the institutional, policy and personal levels remain the directing principles. Basically, unyielding economic control and social manipulative control is of more importance and priority than mere ethnic origin. After all, many of the oppressed zones in Nigeria, which have now surrendered to complacency and agitation, have shared something in common elite complicity. This is seen in the fact that their traditional and national elites have participated in the physical and spiritual destruction of their own peoples.

\section{Nigeria as a Contested Concept and the Problem of Community and National Unity}

There is an immediate consequence of the above experience. This is the fact that a prevalent problem adversely affecting the country Nigeria has not been addressed satisfactorily. This problem has to do with the character and consequences of a gap in our nation building aspiration. Specifically, we are concerned about the absence of a formed mindset towards mutual respect and cooperation among the different groups in the society. Put simply, we are concerned about the spirit of nationalism that is absent in 
the conduct of the members of the society and the various effects of this have threatened the very fabric that keeps our society hanging together by the thread. There is little or no loyalty to the country. There is no core value to serve as a binding force of social order. There is a low level of commitment and patriotic behavior to reinforce the self concept or identity and achievements of the Nigerian peoples. Put more technically this nationalism shortfall is observed in the gap in the nation building aspiration which has to do with the quest for community or how human beings in the society can develop a sense of shared values, a sense of belonging and a purpose of mutual cooperation and reciprocity for the common good.

The absence of strong shared values that can go beyond the interpersonally guided cultural and social domains of life in order to impact on the domain of national ideology and political order is a serious deficit within the construction of social order in Nigeria. Put simply, primordial sentiments such as religion and ethnicity have become primary values and directing principles of social and institutional life in the country. This shortfall of political unity has led to certain dissatisfactions and imbalances within the country's socio-political fabric, thereby truncating the quest for stable and viable social order. The key weak points found in the society at the social and political lead to a nationality problem. This problem is simply the quest for a way that the members of the society can be integrated positively in order to build up a national identity. Hence, there is an emergence of the national question or the nationalism problem.

Put simply the nationality question is partly about the issue of how the human beings living in the country Nigeria can effectively see themselves as first and foremost Nigerians rather than as people from one ethnic or religious affiliation or the other. The issue is sensitive because of the linkage between ethnic identity and diversity that triggers a wider local- global political interest that can be manipulated, abused to foment violence, tension, conflicts and instability in the society. Ethnicity appears to be a threat to building the national spirit in Nigeria. In the first place the thrust or 
focus of nationalism is to establish certain values that can bind homogenous or diverse peoples together primarily for attaining liberation, peace and progress. One question is: is it the case that ethnicity or other parochial interests can be the basis for building a humane and harmonious Nigerian society?

It seems most societies continue to seek ways of evolving and establishing such core values from primordial instincts or contractual obligations. There is a concern over the ability of the members of the society to work together for a common interest despite their different inclinations, and where there is a disagreement of values or interest there should be a way of seeking amicable resolution or consensus for the common good so that some defined focus or interest serves as the directing principle or binding force of all social action. The concern then is to find out that principle or construct or a set of such, if any, that can define the national spirit and serve as a means of establishing and sustaining a coherent national ideology for cooperative and coordinated action to ensure an image of a good society at the individual, group and government levels.

This desire to pursue a national interest needs to be ultimately constructed as a duty of perfect obligation that can be exacted from all citizens. So there is a need for an architecture of nation building, a design for eliciting the nationalistic fervor in members of the society, a programme for establishing and sustaining a humane and equitable social order. The real concern here is that Nigeria does not seem to have an over arching value that guides all social life and national interest. This speaks a lot about the way our society evolved and how it is capable of engaging its members through domestic strategy and the outside world via foreign policy. Otherwise, if our society currently has such an elemental value, then it is at the moment not immanently effective. The quest is for a core value that is above and beyond politics or other mundane or parochial interest; one that all citizens regardless of belief, creed or leaning would accept and uphold. This view of a nationalistic collective interest is aimed at fashioning a sense of belonging for nation building element or social development. 
There is the present challenge of what we may refer to as a divided loyalty, a pursuit of divergent even antithetical visions and goals running against the national or collective interest. This is the root of the problem which simply is that: first, there is no evidential element of sustainable national unity other than the erecting of 'props' of unity using the occasional ceremonial aspect of sports and state festivals. More importantly, there is a need to establish a fundament of nationalism and national unity through some sort of negotiation or identification of a primitive yet consensually established core value which will be non-negotiable to all social members. Such a value will require a philosophical justification as a way of pressing for its non- susceptibility to political and other sorts of manoeuvering and manipulation by social and ideological forces and interests. This implies that our concept or construct will need to be amenable to the elements or essentials of human nature and the basic building blocks of social order. In any case the present unsatisfactory situation of human discord, lack of focus, and instability in the Nigerian society can be traced to a number of factors.

One of the key reasons for this gap of poor cohesion and disunity identified in the pursuit of nationalism or the mindset of placing the greater interest of the Nigerian society as a priority is that there are parochial and egoistic interests arising from ethnicity, class, politics and religion, which trigger the tendency to people creating primordial and syndicated empires for themselves. This ethnic proclivity or inclination makes building social action for a cohesive and public morality quite difficult to attain in a society that suffers from social and ethical shortfalls. This draws our attention to that dislocation in a social system that urgently requires a holistic management of human affairs. The real consequences of this are that divisive elements such as corruption, low level of patriotism, low intensity wars, lack of social and educational opportunities, religious and ethnic conflicts and inefficient systems of procedural justice and the procedures for upholding the rule of law are aggravated thus attacking the moral fabric and legal framework of the society. 
Due to these challenges of differentiation and disconnection, the people are unable to feel and act in ways that promote the common interest. This is especially true of those marginalized groups in the society who by virtue of their varied historically significant plights, are basically not able to speak with one voice nor are they able to make a distinct or decisive choice to pursue harmony, cohesion and cooperation for the common good. The other side of this coin is the problem of leadership action and vision which seems to pursue a selective humanism whereby some persons are seen as superior to others at the level of obedience to the rule of law and adherence to the dictates or axioms of procedural justice.

This situation of a lack of social justice, national distrust, discriminatory practices, social disunity and imbalances in economic distribution raises serious concerns about the prospects for building an enduring sense of belonging, peace and progress in Nigeria. Hence we are compelled to ask: Where lies the possibility or capability for a revolution, otherwise, the quest for a systematic change in social order for the harmonization of interests in view of the common good and public interest? How do the citizens become truly republican in the sense of pursuing the public good always and showing interest to serve the collective interest of the Nigerian society? How do we build a social system whereby individuals can make their primary contributions to the society in their defined roles and functions as citizens of Nigeria rather than pursue a tribal or ethnic inclination or vision? So the question is to look for ways by which members of the Nigerian society can move beyond the strictures of ethnicity towards membership of a socially just, economically viable and equitable and politically responsive and culturally reconciliatory humane society.

The issue here therefore, is to identify and theorize some strategies and principles that can push members of the society to consider themselves as Nigerians first and foremost before seeing themselves in any other role- president, a member of any of the armed forces, a person from a particular tribe, a business man or whatnot. To what extent is it possible to manage Nigeria's diversity so that our differences will not obstruct our desire or effort to be 
cohesive? The question will be what options are available? Should we return to some legal and constitutional frameworks for establishing a viable, stable and progressive social order where everyone will see themselves as truly Nigerian? What can we do with the appeal by some persons for us to return to regionalism where specific regions are allowed to fashion their strategies and philosophies of human and social development so as to grow at their own pace. How can we use the tools of federalism to pursue fair economic distribution of resources, equitable social justice mechanisms and the relatively unhindered development of the different states and regions at their natural evolutionary pace?

\section{Conclusion: The Imperative of a Philosophy of Society or Social Philosophy as a Foundation of a Stable and Viable National Integration}

In looking at the urgent desire to establish a philosophy of security and more importantly, sustain alternative mechanisms of social control and progress Awa (1993:58) has rightly stated "where societies are poorly integrated and primordial feelings are prevalent as in the states of Africa, the representatives of the various ethnic groups in the civil service may perceive the national interest mainly in terms of the welfare of their particular groups." Higher ideals and positive values must be encouraged and entrenched. If ethnicity is allowed to continue ravaging the spaces, then things will never progress in many parts of Africa. Thus far, ethnicity has largely brought prominent negative aspects to African societies, inhibiting morality, education, religion, law and other instruments that have changed societies for the better elsewhere. It is for these fundamental reasons that some groups have called for the aesthetical reconfiguration of the society through instruments such as the sovereign national conference, self-determination declarations, political realignments, and non-violent agitations for resource control. Other instruments include outright militia violence, social activism for attrition and persistently radical legal actions for widespread national liberation and transformation. This 
in turn raises the question of tolerance and dialogue as instruments for change in a multiethnic developing society.

We can explore prospects for a solution in a theoretical manner by reviewing the conditions for a philosophy of society. The search for a philosophy for society is not new in human history or the history of human civilizations. In the unique case of America, it has generated a pragmatic philosophy that has ensured its distinctness, success and ascendancy in history. Other societies have done similar things some have even developed a viable philosophy by combining different elements of life borrowed from within and outside their national spaces. A philosophy of society is fashioned out of a climate of beliefs, behaviour and actions. The climate of a society depends upon the ideas that are prevalent at the time (Viscount Samuel 1956:208). The climate of social life needs to be underwritten by a social philosophy that should abide by the core value of respect for the principle of the value of human life, understood as respect for the dignity of man in his freedom and responsibility. The recognition of the value of life is an imperative, if any social philosophy is not to suffer the failures associated with the old communalism (which generated hegemony, anachronism, irredentism and disaffection) and crass pragmatism (which generated manipulation, irrelevance, otherness and cultural disdain) in the body polity. In the pursuit of an alternate philosophy of social life understood as a pristine value or an eclectic mix, the value of human life as a moral and political core of any viable social philosophy is to be taken as sacrosanct and consecrated.

The practical consequence of the recognition of the value of human life is the intensification of the mechanisms and strategies for the establishment and sustenance of justice in the society. The ontology and axiology of justice will trigger the arousal of a deep belief in the power and capacity of the society, its custodians and its institutions to make a change towards the assurance of the freedom, well-being, opportunities and progress of the generality of the citizens. A philosophy of Nigeria is nothing other than the totality of the principles, values, concepts and structures that will 
ensure that individuals give a fuller loyalty and commitment to the society and can have the best opportunities for actualizing their potentials and making their contributions.

\section{References}

Azikiwe, Nnamdi. "Essentials for Nigerian Survival." Foreign Affairs 43.3 (1965): 447. Print.

Bottomore, T., Encyclopedia of Government and Politics. Ed. Mary Hawkesworth and Maurice Kogan. New York: Routledge, 1996. Print.

Brown, Lester R., and Lester R. Brown. Plan B 3.0: Mobilizing to save Civilization. New York: W.W. Norton, 2008. Print.

Calvocoress, Peter. World Politics. 7th Edition ed. London: Longman, 1997. Print.

Odion-Akhaine, Sylvester, B. U. Chizea, and Nonso Uchegbu. State of Human Rights in Nigeria. Lagos: Centre for Constitutionalism and Demilitarisation, 2011. Print.

Shaw T M., State of Human Rights in Nigeria. Lagos: Centre for Constitutionalism and Demilitarisation, 2012. Print.

Raji, Wumi, Ayodele Ale, and Eni Akinsola. Boiling Point: A CDHR Publication on the Crises in the Oil Producing Communities in Nigeria. Lagos: Committee for the Defence of Human Rights, 2000. Print.

Diamond, Larry. "Introduction: Roots of Failure, Seeds of Hope." Democracy In Developing Countries: Africa. Diamond L. et al., Vol. 2. Lagos: Boulder-Colorado, 1998. Print.

Rienner, Lynne. "Nigeria: Pluralism, Statism and the struggle for democracy." Democracy In Developing Countries: Africa. Diamond L. et al., Vol. 2. Lagos: Boulder-Colorado, 1998. Print. 
Glazer, Nathan, and Berkeley Moynihan. Beyond the Melting Point: The Negroes, Puerto Ricans, Jews, Italians, and Irish of New York City. Cambridge: M.I.T., 1963. Print.

Glazer, Nathan, and Berkeley Moynihan. Beyond the Melting Point: The Negroes, Puerto Ricans, Jews, Italians, and Irish of New York City. Cambridge: M.I.T., 1963. Print.

Graf, William. "African Elite Theories and Nigerian Elite Consolidation: A Political Economic Analysis." Political Science in Africa. Ed. Barongo Y. London: Zed, 1983. 189-210. Print.

Gyamfi, Charles Coffie. "Our Story of Social and Economic Breakdown." The Guardian [Lagos] 1 Oct. 2010: 11. Print.

Hawthrone, Geoffrey. "Sub-Saharan Africa." Prospects for Democracy. Ed. D. Held. Cambridge:Polity, 1993. 330-54. Print.

Ibrahim, Jibrin. "Obstacles to Democratization in Nigeria." Dilemmas of Democracy in Nigeria. Ed. P. Beckett and C. Young. Rochester, NY, USA: U of Rochester, 1997. 155-74. Print.

Ifeka, Caroline. "Conflict, Complicity and Confusion: Unraveling Empowerment Struggles in Nigeria After the Return to Democracy." Review. Review of African Political Economy (2000): 83. Print.

Kemp, Tom. Industrialization in The Non-Western World. 2nd ed. London: Longman Group, 1998. Print.

Kitchen, Helen. "Nigeria." Educated African: A Country By Country Survey of Educational Development in Africa. Ed. Frederick A. Praeger. New York, 1962. Print.

Engels, Freidrich, and Karl Marx. "Manifesto of the Communist Party." Great Books of the Western World. Ed. Mortimer J. Alder. Chicago: Encyclopaedia Britannica, 1990. Print.

Nielsen, Kai. "Conceptions of Justice." Encyclopedia of Government and Politics. Ed. Mary Mary Hawkesworth. Vol. 1. London: Routledge, 1996. Print. 
Nisbet, Robert. "The Quest for Community." Dialogue 6.4 (1973): 1321. Print.

Nzimiro, Ikenna. Nigerian Civil War: A Study in Class Conflict. Enugu, Nigeria: Frontline Pub., 1984. Print.

Odugbemi, Sina. "Ethnic Nationalism and the Future of Nigeria." RECALL 2 (2001): 66-75. Print.

Ogunrotifa, Ayodeji Bayo. "Class Theory of Terrorism: A Study of Boko Haram Insurgency in Nigeria." Research on Humanities and Social Sciences 3.1 (2013): 27-59. Print.

Osha, Sanya. "Slow Death in the Niger Delta." Rev. of Where Vultures Feast: Shell, Human Rights and Oil. Africa Review of Books 2.1 (2006): 14-15. Print.

Otite, Onigu. Nigeria, towards Salvaging a Ravaged Society. Ibadan: U of Ibadan, 1996. Print.

Ozohu-Suleiman, Abdulhamid, and Samuel Baba. "Crime Prevention and Control in Nigeria: Institutional Failure and the Option of Food Security." The Constitution 9.4 (2009): 42-60. Print.

"Report of the Technical Committee on the Niger Delta 2008." The Constitution 10.1 (2010): 82-132. Print.

"Report of the Special Security Committee on Oil Producing Areas (Ogomudia Report) 2002." The Constitution 7.3 (2007): 120-56. Print.

Said, Abdul Aziz. "Pursuing Human Dignity." Soc Society 15.1 (1977): 34-38. Print.

Seton-Watson, H. Nations \& States: An Inquiry into the Origins of Nations and the Politics of Nationalism. London: Methuen, 1977. Print.

Ujomu, Philip Ogo. "Nigeria's National Security Problematic and the Reinvention of Social Order: Some Aesthetic Considerations." The Constitution 9.1 (2009): 21-37. Print. 
Usman, Bukar. Voices in a Choir: Issues in Democratization and National Stability in Nigeria. Kaduna: Klamidas, 1999. Print.

Uroh, C.O., ed. Africa and the Challenge of Development: Essays by Samir Amin. Ibadan: Hope, 1998. Print.

Viscount, Samuel. "Philosophy and the Life of the Nation." Philosophy 31.118 (1956): 197-212. Print. 